\title{
Contribution to the knowledge of selected genera of the tribe Opsiini (Hemiptera: Cicadellidae: Deltocephalinae) from the Kingdom of Saudi Arabia
}

\author{
Saad EL-SONBATI ${ }^{1)}$, Michael WILSON ${ }^{2)} \&$ Hathal AL DHAFER ${ }^{1,3)}$ \\ ${ }^{1)}$ King Saud University Museum of Arthropods, Plant Protection Department, College of Food and Agriculture Science, King Saud University, P. O. \\ Box 2460, Riyadh 11451, Saudi Arabia; e-mails: anase24@yahoo.com, ssonbati@gmail.com, ssonbati@ksu.edu.sa \\ 2) Department of Natural Sciences, National Museum of Wales, Cardiff, CF10 3NP, Wales, United Kingdom; e-mail: mike.wilson@museumwales.ac.uk \\ ${ }^{3)}$ E-mail: hdhafer@ksu.edu.sa
}

Accepted:
$2^{\text {nd }}$ July 2018
Published online:
$1^{\text {st }}$ August 2018

\begin{abstract}
The redescriptions of two genera of Opsiini (Hemiptera: Cicadellidae), Concavifer Dlabola, 1960 and Phlepsopsius Dlabola, 1979, are given based on specimens collected recently in the Kingdom of Saudi Arabia. Concavifer nativus Zhuravlev, 1991 syn. nov., and C. sagittatus Emeljanov, 1972 syn. nov. are proposed as new subjective junior synonyms of C. marmoratus Dlabola, 1960. Phlepsopsius africanus Abdul-Nour, 2007, syn. nov., is proposed as a new subjective junior synonym of $P$. arabicus Dlabola, 1979. The genus Hishimonus Ishihara, 1953 is newly reported for the Kingdom of Saudi Arabia, represented by the species H. phycitis (Distant, 1908). A key is provided to distinguish the species of Concavifer.
\end{abstract}

Key words. Hemiptera, Auchenorrhyncha, Cicadellidae, leafhoppers, taxonomy, new synonymy, distribution, Arabian Peninsula, Palaearctic Region

ZooBank: http://zoobank.org/urn:1sid:zoobank.org:pub:832A060E-85F5-49B3-B2A4-5FE358A53DAA

(C) 2018 The Authors. This work is licensed under the Creative Commons Attribution-NonCommercial-NoDerivs 3.0 Licence.

\section{Introduction}

The Deltocephalinae is considered one of the most important groups of leafhoppers (Hemiptera: Cicadellidae) due to the number of species and genera, their abundance and ability to transmit plant diseases (NIELSON \& KNIGHT 2000, ZAHNISER \& DieTrich 2008). Among the deltocephaline tribes the Opsiini, with more than 300 species, contains a large number of vector species. It is divided into four subtribes, two of which are represented in Saudi Arabia: Circuliferina and Opsiina (DMitriev 2002, ZAhNiser \& DIETRICH 2013). Although Opsiina is widespread mainly in the tropical regions of the Old World, some genera are also present in the Palaearctic Region, such as Opsius Fieber, 1866 and Hishimonus Ishihara, 1953. The subtribe Circuliferina is commonly represented in the Palaearctic Region, and the genus Concavifer Dlabola, 1960 appears endemic in this region (EMELJANOV 1962, ZAHNISER \& DIETRICH 2013).
Despite studies of the Cicadellidae in the Kingdom of Saudi Arabia (KSA) by Dlabola $(1979,1980,1987)$, and recently, the taxonomic papers of EL-SONBATI et al. (2015, $2016,2017)$, it is now apparent that the leafhopper fauna is much more diverse in the country than previously considered. Recent fieldwork has found many more genera and species new to the Arabian fauna. Prior to this study, Opsiini from KSA were represented by seven genera: Concavifer, Neoaliturus Distant, 1918, Opsius, Oshaibahus El-Sonbati \& Wilson, 2017, Paraorosius El-Sonbati \& Wilson, 2016, Orosius Distant, 1918 and Phlepsopsius Dlabola, 1979. Some poorly known species of these genera require additional studies. Two of the above known genera, Concavifer and Phlepsopsius are treated herein, and Hishimonus is recorded here as another Opsiini genus for the first time for KSA.

The genus Concavifer was erected by Dlabola (1960), with Concavifer marmoratus Dlabola, 1960 designated 
as the type species. Originally found at several localities in Iran (Dlabola 1960), it was later listed also from KSA (Dlabola 1979). Later other Concavifer species have been described: C. sagittatus Emeljanov, 1972 from Mongolia (Emeljanov 1972); C. bolkarensis Kartal, 1982 from Turkey (Kartal 1982); and C. nativus Zhuravlev, 1991 from Kazakhstan (ZHurAvLev 1991). In the present study, the genus is redescribed and $C$. sagittatus and $C$. nativus are both proposed as junior subjective synonyms of C. marmoratus.

Phlepsopsius was described from KSA based on P. arabicus Dlabola, 1979 as the type species (Dlabola 1979). Later, P. africanus Abdul-Nour, 2007 from Libya was accommodated in the genus (ABDUL-Nour 2007). In this paper, Phlepsopsius is redescribed based on the type species, $P$. arabicus. Phlepsopsius africanus is proposed as a junior subjective synonym of $P$. arabicus.

Hishimonus currently includes more than 50 species known from the Oriental, Palaearctic, Afrotropical and Australasian Regions (ZAHNISER 2018, FLeTCHER \& DAI 2018). Hishimonus phycitis (Distant, 1908) has been reported as a vector of the Witches' broom disease of lime (WBDL) (Zreik et al. 1995, ShabANi et al. 2011). WBDL is associated with 'Candidatus Phytoplasma aurantifolia', considered one of the most lethal plant pathogens (MARDI et al. 2011, SHABANI et al. 2013). WBDL is widely distributed in the Arabian Peninsula and especially Oman (with 98\% loss of lime trees) and the United Arab Emirates. But it was also found in India and Iran (30\% of Mexican lime trees over half a million trees/7000 hectares) (ZREIK et al. 1995, Parrella et al. 2008, MARdi et al. 2011, Al-SAleh \& AMER 2014). Interestingly WBDL has been reported from KSA but with Empoasca decipiens Paoli, 1930 (Cicadellidae: Typhlocybinae: Empoascini) as a vector responsible for major losses, estimated at 25\% loss of lime trees (AlHUDAIB et al. 2009).

\section{Material and methods}

Voucher specimens of each species are deposited in the following collections:

KSMA King Saud University Museum of Arthropods, College of Food and Agriculture Sciences, King Saud University, Riyadh, KSA;

NMWC National Museum of Wales, Cardiff, UK;

NHMO Natural History Museum of Oman;

NAWRC National Agriculture and Water Research Centre, Riyadh, KSA;

MNHN Muséum national d'Histoire naturelle, Paris, France.

Morphological terminology follows DieTRICH (2005). Measurements are in millimeters (mm). All specimens were examined with a Leica LABOPHOT-2 stereomicroscope. Illustrations of the male genitalia were prepared using a NIKON microscope with a drawing tube attachment. Images were taken with a Canon 70D DSLR attached to a Leica Z6 microscope. Individual source images were then stacked using Helicon Focus v. 6.22 software, with calibrated scale bars added using Syncroscopy Automontage v. 5.4. The maps in Figs 51-52 were created using the ArcGIS 10.3 software.

\section{Results}

\section{Concavifer Dlabola 1960}

Concavifer Dlabola, 1960: 14. Type species: C. marmoratus Dlabola, 1960 , by original designation.

Diagnosis. Concavifer can be recognized by the following combination of characters: crown sharply angled to face; pygofer with well-developed appendages; style bent, small, finger-like, curved preapically, the curve in dorsal view rounded at the apex; aedeagus with two branches, forming a semi-circle in ventral view.

Redescription. Measurements. Body length: male 3.9-4.1 $\mathrm{mm}$; female 4.0-4.5 $\mathrm{mm}$.

Coloration (Figs 1-2, 7-8). Generally yellowish, with brownish spots. Pronotum and forewings with a brown streaked pattern. Pronotum yellowish brown with pale midline. Forewings with brown spots, larger spots only at the inner edge. Face yellow. Vertex with two oblique V-shaped brown spots, with or without distinctive oval brown spots. Scutellum orange, brown spotted at lateral angles. Legs yellow and mottled with brown, with brown setal areolae.

Structure. Head (Figs 1-2, 7-8) as wide as pronotum. Crown twice wider than each compound eye, elongate medially, concave, sharply angled to face. Gena slightly incised with single fine erect seta near lateral frontal suture. Lateral frontal suture reaching ocellus and directed mesad of ocelli. Frontoclypeus longer than wide. Clypeal suture straight and complete. Clypellus narrower than lorum at base, slightly expanding towards apex in basal two thirds, greatly produced beyond gena with apical margin straight. Lorum apex widely distant from gena margin. Antenna inserted near posteroventral corner of eye, mesal margin of eye notched.

Thorax. Pronotum with anterior margin convex and posterior margin slightly concave, wider than long. Combined length of mesoscutum and scutellum equal to their width. Macropterous, forewing veins not carinate, appendix restricted to anal margin, with three anteapical cells, without reflexed costal veins, A1-A2 crossvein absent, r-m1 crossvein present. Hindwing submarginal vein complete.

Legs. Profemur row AM with AM1, one intercalary row with more than five fine setae gradually reduced apically, two dorsoapical setae. Protibia AD row with four duplicate macrosetae, AV row with numerous macrosetae gradually increasing in size apically. Mesofemur AV row with stout and short setae, two apical setae. Mesotibia AD and AV rows each with four macrosetae. Metafemur setal formula $2+2+1$, second pair with shorter setae. Metatibia PD row with long and short macrosetae, $\mathrm{AD}$ row with macrosetae and three smaller intercalary setae between each pair; AV row with numerous macrosetae extending nearly to base, gradually increasing in size apically. Metatarsomere I as long as tarsomeres II plus III combined.

Male genitalia (Figs 13-26). Pygofer with well-developed appendages arising caudoventrally and extending dorsally but not exceeding pygofer margin, with well-de- 
veloped macrosetae medially, ventral margin long, curved inside (Figs 25-26). Genital valve free and with pointed articulation to the pygofer (Fig. 19). Subgenital plate with one row of macrosetae near margin and some additional scattered hairs short to as long as macrosetae, apical part finger-like, apical part sinuate at lateral side (Fig. 18). Style bent, small, finger-like, curved preapically, the curve in dorsal view rounded at apex, with well-developed preapical lobe and subapical tooth (Figs 20-24). Connective Y-shaped, branches as long as half of connective total length (Fig. 17). Aedeagal shaft with two branches, each curved anteriad, forming a semi-circle in ventral view, each branch with outer side bearing a small membranous appendage preapically, inner side sinuate medially, and apex pointed (Figs 13-16).

Female genitalia (Figs 27-29). Pygofer with numerous macrosetae. Sternite 7 as broad at base as long medially, posterior margin slightly sinuate, with elongated lobe, posterolateral angles acutely rounded (Fig. 27). First valvula convex medially. Second valvula gradually tapered apically with variable serrations on dorsal surface (Figs 28-29).

Remarks. Concavifer is closely related to Neoaliturus: both genera share the aedeagus with two branches forming a semi-circle which is considered here a putative synapomorphy. When describing Concavifer, Dlabola (1960) compared his new genus with Platymetopius Burmeister, 1838 (currently placed in the tribe Athysanini: ZAHNISER \& Dietrich 2013) and Distomotettix Ribaut, 1938 (synonymised under Neoaliturus by LiNNAVUORI 1962). Concavifer was originally diagnosed by the following characters: postclypeus narrow and long, twice longer than distance between ocelli; antenna long; stylus short; genital plate long; and, particularly from Distomotettix, by the male pygofer without an appendage. However, our examination of the type species of the genus, C. marmoratus, showed that the male pygofer in fact possesses an appendage, which was probably overlooked by DlABOLA (1960). EMELJANOV (1999) separated Concavifer and Neoaliturus based on the structure of the head without mentioning the main characters of the genus as given in the diagnosis above. LiNNAVUORI (1962) postulated that Concavifer may be a subgenus of Neoaliturus regardless of the differences in external characters. Our redescription is based on direct examination of $C$. marmoratus, the type species of the genus. We also made attempts to borrow and examine the type material of C. bolkarensis Kartal, 1982, but without success. It cannot be confirmed that this species possesses a pygofer appendage. Additional studies are needed to clarify the relationship between Concavifer and the species currently included in Neoaliturus.

Distribution. Palaearctic Region (OMAN et al. 1990), from Turkey in the west to Mongolia in the east (Fig. 51).

\section{Key to species of Concavifer}

1 Vertex without distinctive 12 oval brown spots. Branches of aedeagus not sinuate laterally, with appendages on outer side preapically and inner side with a tooth medially. Subgenital plate with few scattered hair-like setae.

C. marmoratus Dlabola, 1960

- Vertex with distinctive 12 oval brown spots. Branches of aedeagus sinuate laterally, with a small projection dorsally and inner side without a tooth medially. Subgenital plate with numerous hair-like setae.

C. bolkarensis Kartal, 1982

\section{Concavifer marmoratus Dlabola, 1960}

(Figs 1-2, 7-8, 13-29)

Concavifer marmoratus Dlabola, 1960: 14.

Concavifer sagittatus Emeljanov, 1972: 233, syn. nov.

Concavifer nativus Zhuravlev, 1991: 85, syn. nov.

Type material examined. C. marmoratus: PARATYPES: $2 \hat{\jmath}$, IRAN: Djiroft, Anbar-Abad, 21-30.iv.1956, W. Richter leg. (NMWC).

Additional material examined. KINGDOM OF SAUDI ARABIA: RIYADH: 201 , 20.ix.1979, A. Talhouk, S. Tilkan, R. Abousouheyrah, K. Kltaher \& A. Klmsdi leg.; 1 , same but 16.v.1977 (det. J. Dlabola, 1982; NAWRC); 1 9, Rhodet Khorim (A), 16.x.2011, 25²2.986'N, $47^{\circ} 16.712^{\prime} \mathrm{E}, 559 \mathrm{~m}, \mathrm{H}$. Al Dhafer \& S. El-Sonbati leg.; 1 \% , same but

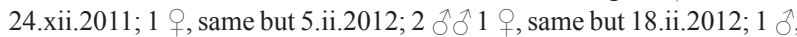
same but 5.iii.2012; 1 ๆ, same but 6.iii.2012; 1 §, same but 31.iii.2012;

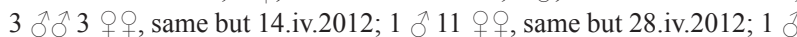
4 우, same but 14.v.2012; 2 우, same but 15.v.2012; 2 우, same but 18.v.2012; 5 \% 4 , same but 26.v.2012; 1 , same but 27.v.2012; 8 ठै่ 1 क , same but 9.vi.2012; 9 के 4 우, same but 10.vi.2012; 3

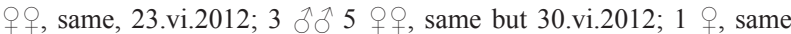
but 28.vii.2012; 1 क, same but 14.x.2012; $1 \hat{\jmath}$, same but 9.iii.2013; 1 o, same but 20.iii.2013; $1 \hat{\jmath}$, same but 15.vi.2013; $1 \hat{\jmath}$, Rhodet Khorim (B), 25.i.2010, $25^{\circ} 25.943^{\prime} \mathrm{N}, 47^{\circ} 13.863^{\prime} \mathrm{E}, 572 \mathrm{~m}$, H. Al Dhafer \& S. ElSonbati leg.; $3 \hat{\partial} \hat{\partial}$, same but 25.xii.2011; $1 \hat{\jmath}$, same but 14.i.2012; $1 \hat{\jmath}$, same but 5.ii.2012; $2 \hat{\delta} \hat{\delta}$, same but 18.ii.2012; 1 , same but 5.iii.2012;

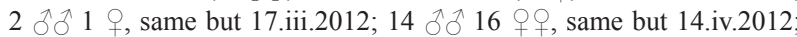
$2 \hat{\delta}$ same but 28.iv.2012; $9 \hat{\delta} 11$ 우, same but 29.iv.2012; 1 त 1 , same but 14.v.2012; 3 2 9 , same but 15.v.2012; 1 , same but 26.v.2012; $2 \hat{\delta} 1$, same but 27.v.2012; 1 , same but 9.vi.2012; 2 तิ 3 우, same but 10.vi.2012; 3 ते 1 ㅇ, same but 24.vi.2012; 1 , same but 30.vi.2012; $2 \hat{\delta} 5$ 우, same but 28.vii.2012; 5 우, same but 28.viii.2012; $4 \hat{\jmath}$, same but 14.x.2012; $1 \hat{\jmath}$, same but 20.iv.2013; $1 \hat{\jmath} 1$ $q$, same but 11.v.2013; $1 \curvearrowright 1$, same but 20.vi.2013; 1 , Muzahimiyah,

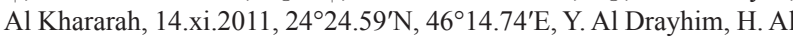
Dhafer, A. El-Gharbawy \& M. El Motairy leg.; $4 \hat{\jmath} \hat{\jmath}$, same but 17.iv.2012, H. Al Dhafer, H. Fadl, M. Abdel-Dayem, A. El Torky \& A. Al-Ansi leg.; $1 \lesssim 1$, Az Zulfi, Rhodet Al Sabalah, 19.v.2015, 26²1.624'N, 445․ $010^{\prime}$ E, 669 m, H. Al Dhafer, M. Abdel-Dayem, A. El Torky, A. El-Gharbawy \& A. Soliman leg.; 1 đ̃, Tumair, 19.v.2013, $25^{\circ} 42.36^{\prime} \mathrm{N}$,

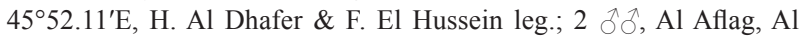
Naifiyah, Farshet Sheaal, 10.iv.2015, 22 ${ }^{\circ} 24.935^{\prime} \mathrm{N}, 4^{\circ} 35.287^{\prime} \mathrm{E}, 599$ m, H. Al Dhafer, M. Abdel-Dayem, A. El Torky, A. El-Gharbawy \& A. Soliman leg.; 1 9, Wadi Namar, 29.ii.2012, 24³4.222'N 46²0.672'E, A. Al-Ansi, M. Al-Harbi \& A. Al-Othman leg.; $8 \curvearrowright 6$ 우, Ibex Reserve National Park, Wadi Hutet Beni Tamem, 180 km S of Riyadh, 7.v.2012, $23^{\circ} 27.133^{\prime} \mathrm{N}, 46^{\circ} 41.281^{\prime} \mathrm{E}, 676$ m, H. Al Dhafer, M. Abdel-Dayem, A. El Torky \& A. Al-Ansi leg. (all KSMA, NMWC). OMAN: SchamaL ASCH-SChARQIYYA: 1 , Al Mudaibi, Samad, Ashan, Aswareeg, $22^{\circ} 49.5^{\prime} \mathrm{N}$ 58 09.117'E, 9-10.viii.2017, A. Al Jahdhami leg.; 1 , same but 7-10. vii.2017; 1 , same but 1-10.x.2017 (all KSMA, NHMO).

Diagnosis. Based on the published description of C. bolkarensis (KARTAL 1982), C. marmoratus can be distinguished from $C$. bolkarensis by the characters given in the key above.

Redescription. Measurements. Body length: male 3.9-4.1 $\mathrm{mm}$; female 4.0-4.5 $\mathrm{mm}$. Crown twice wider than eye width, $0.5 \mathrm{~mm}$ long medially and $0.4 \mathrm{~mm}$ broad between 

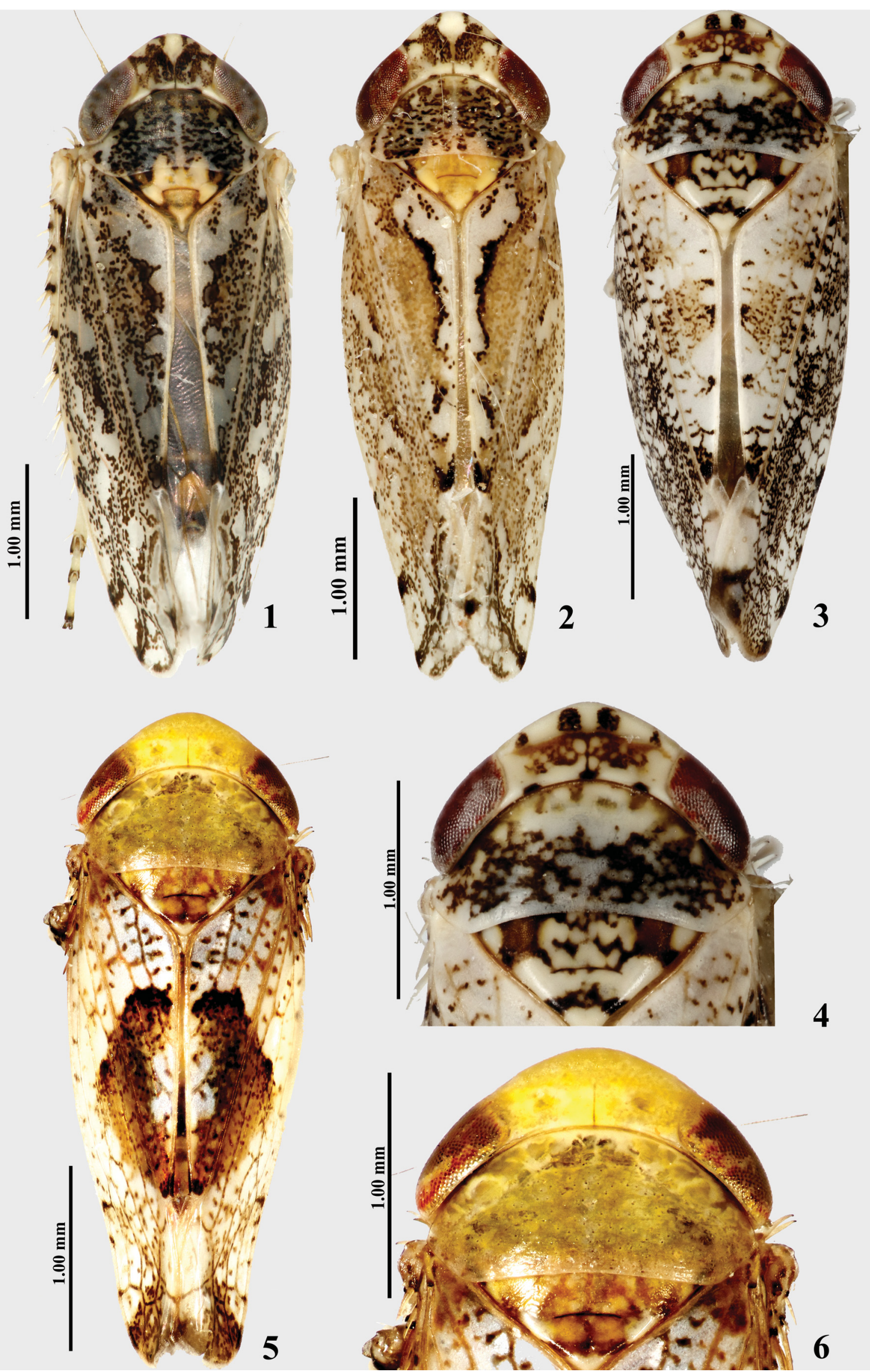

Figs 1-6. 1-2-Concavifer marmoratus Dlabola, 1960: 1 - dorsal view of male; 2- dorsal view of female. 3-4 - Phlepsopsius arabicus Dlabola, 1979: 3 - dorsal view; 4 - head and thorax. 5-6 - Hishimonus phycitis (Distant, 1908): 5 - dorsal view; 6 - head and thorax. 


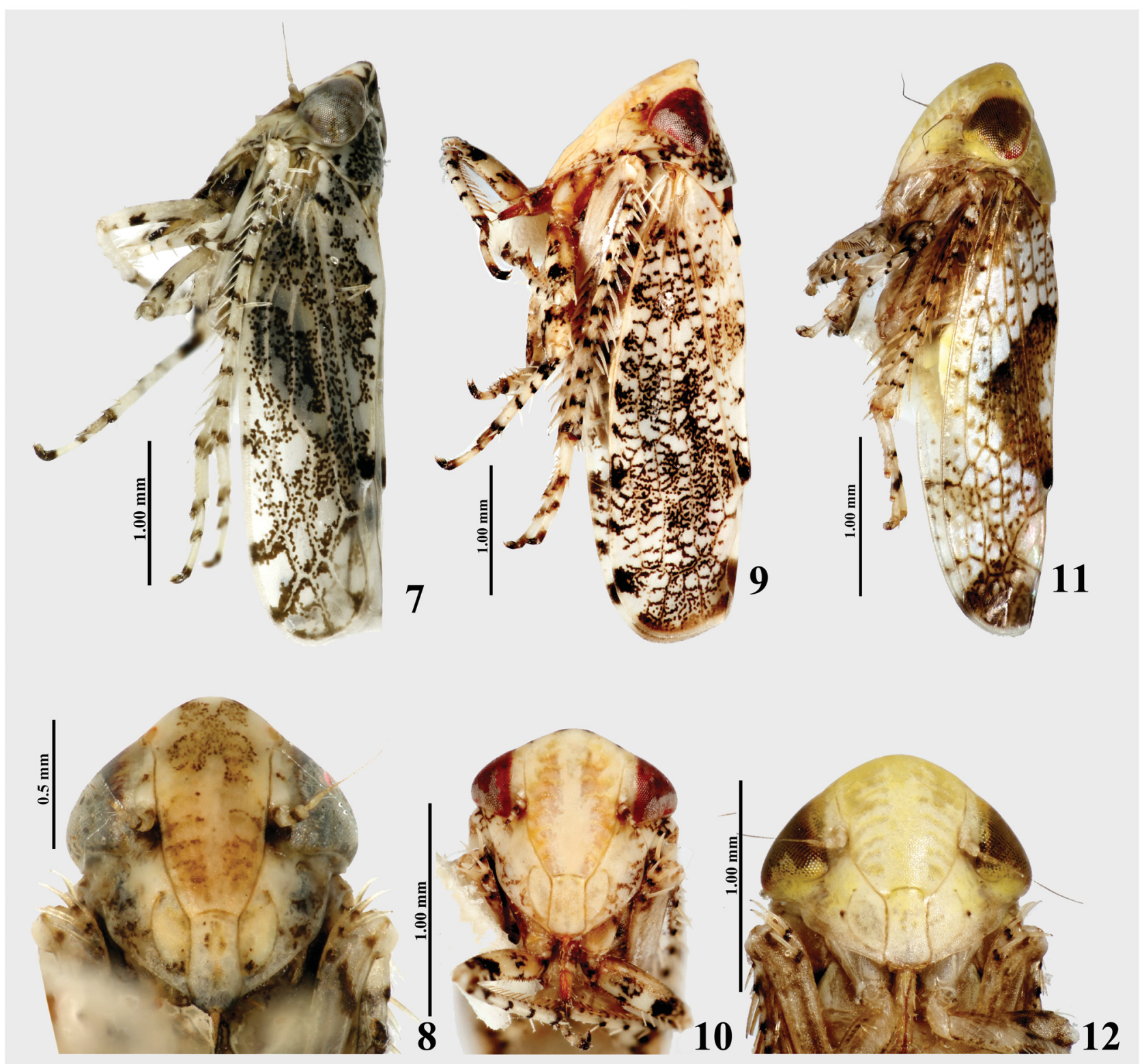

Figs 7-12. 7-8 - Concavifer marmoratus Dlabola, 1960: 7 - lateral view; 8 - face. 9-10 - Phlepsopsius arabicus Dlabola, 1979: 9 - lateral view; 10 face. 11-12 - Hishimonus phycitis (Distant, 1908): 11 - lateral view; 12- face.

eyes. Pronotum wider $(0.7 \mathrm{~mm})$ than long $(0.5 \mathrm{~mm})$. Combined length of mesoscutum and scutellum $0.4 \mathrm{~mm}$ (as wide as long). Forewing length $3.1 \mathrm{~mm}$.

Coloration and structure. See the generic redescription. Ecology and biology. This species was commonly found in the Rawdhat Khorim (= Rhodet Khorim) National Park situated in the Central KSA (Fig. 53), which has a diverse flora of 153 plant species within 32 families (ALFARHAN 2001). Concavifer marmoratus was collected there on Lycium shawii Roem. \& Schult. (Solanaceae) but there were many other plant species in the surroundings, e.g. Acacia gerrardii Benth. (Fabaceae) and Rhazya stricta Decne. (Apocynaceae). No further biological information is available and no assessment of any economic importance of Concavifer has been reported yet.
Distribution (Figs 51-52). Iran (Dlabola 1960), Kingdom of Saudi Arabia (Dlabola 1979, this paper), Mongolia (Emeljanov 1972), Kazakhstan (Zhuravlev 1991), Palestine (LinNAVUORI 1962).

Remarks. Concavifer nativus Zhuravlev, 1991 and $C$. sagittatus Emeljanov, 1972 are treated herein as new subjective junior synonyms of $C$. marmoratus. EMELJANOV (1972) and ZHURAVLEV (1991) distinguished their newly described species from $C$. marmoratus based only on Dlabola's original illustrations of the stylus. However, Dlabola (1960) did not illustrate the stylus structure correctly, which is demonstrated here by a study of paratypes from Iran and additional specimens from KSA originally identified by Dlabola. These specimens, as well as numerous additional specimens from KSA, Iran and 


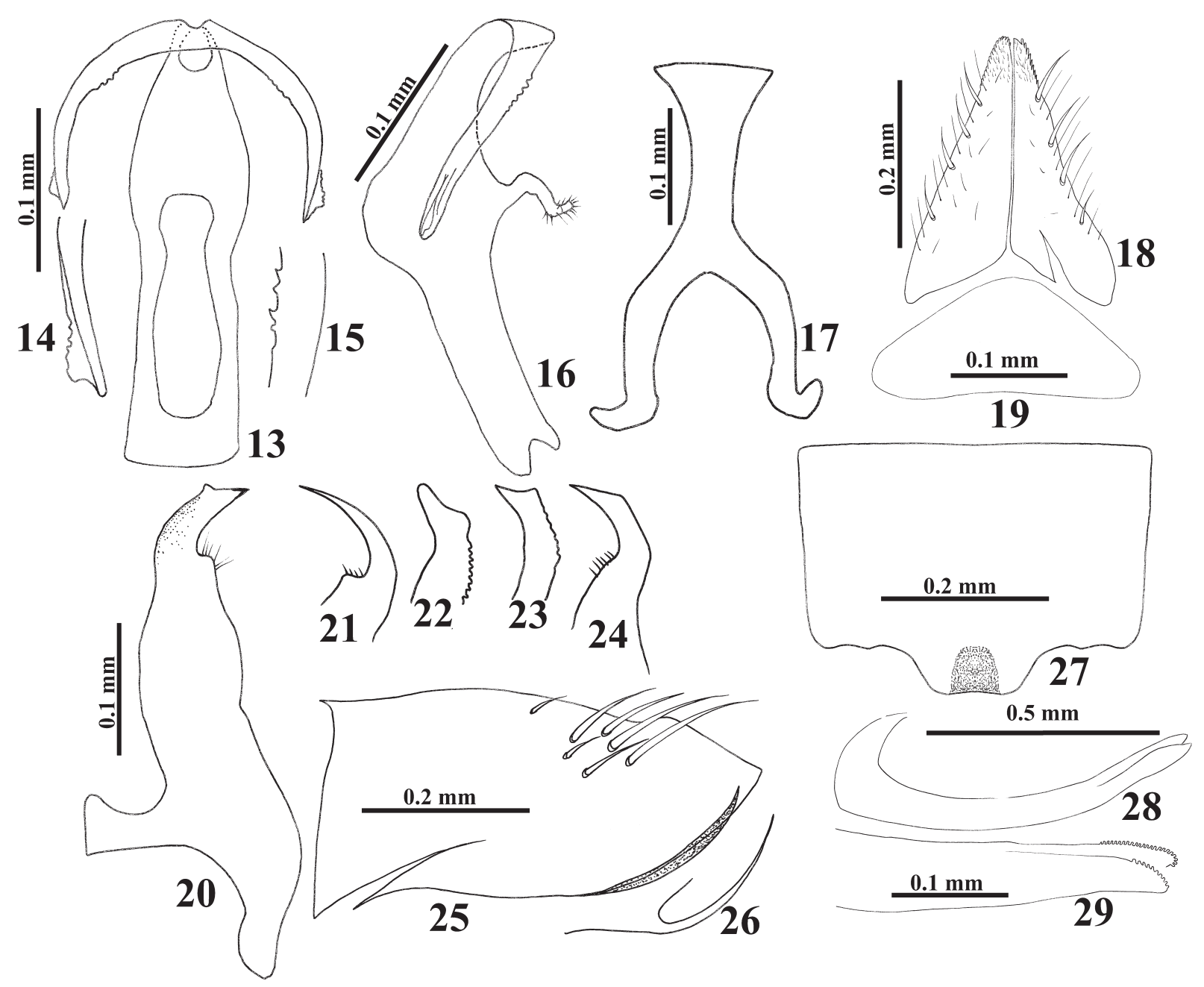

Figs 13-29. Concavifer marmoratus Dlabola, 1960. 13 - aedeagus, dorsal view; 14 - aedeagus, detail of apex of lateral branch, dorsal view; 15 - aedeagus, detail of median part of lateral branch, dorsal view; 16 - aedeagus, lateral view; 17 - connective; 18 - subgenital plate; 19 - valve; 20 - style; $21-24$ different views of style; 25 - pygofer; 26 - pygofer appendage; 27 - female 7th sternite; 28 - ovipositor, lateral view; 29 - detail of ovipositor apex.

Oman fully agree with characters specified in the original descriptions of $C$. nativus and C. sagittatus.

\section{Phlepsopsius Dlabola, 1979}

Phlepsopsius Dlabola, 1979: 132. Type species: Phlepsopsius arabicus Dlabola, 1979, by original designation.

Diagnosis. Phlepsopsius can be recognized by the following combination of characters: general colour greyish white with tinge of yellow, with some extremely dense brown mottling, particularly on forewings behind base; crown sharply angled to face; aedeagus with shaft bifurcate, each branch as long as two thirds of the total aedeagus length, curved dorsad in lateral view; aedeagus basally with long bifurcate process, pointed at apex, curved dorsad in lateral view and curved mesiad apically in dorsal view. Redescription. Measurements. Body length: male 4.2-4.6 $\mathrm{mm}$; female $4.3-4.8 \mathrm{~mm}$. Crown width $1.6 \mathrm{~mm}$, crown length $0.6 \mathrm{~mm}$. Pronotum width $1.6 \mathrm{~mm}$, pronotum length $0.6 \mathrm{~mm}$. Scutellum width $0.8 \mathrm{~mm}$, scutellum length 0.5 $\mathrm{mm}$. Forewing length $3.5 \mathrm{~mm}$.

Coloration (Figs 3-4, 9-10). Ground colour greyish white with tinge of yellow, with some extremely dense brown mottling, particularly on forewings behind base. Face yellow. Vertex with two oblique V-shaped brown spots and two small spots laterally, posterior margin with three small spots. Pronotum yellowish brown, with pale area beyond vertex and incomplete rows of spots forming a net-like pattern. Forewings with brown spots in incomplete rows forming a net-like pattern. Legs yellow and mottled with brown, all spines arising from brown base. Legs with brown setal areolae.

Structure. Head (Figs 3-4, 9-10). Head slightly narrower than pronotum; crown twice wider than distance between eyes, slightly produced medially, sharply angled to face. Gena slightly incised with single fine erect seta near to lateral frontal suture. Lateral frontal suture reaching ocellus and directed mesad of ocelli. Frontoclypeus longer than wide. Clypeal suture arcuate and complete. Clypellus narrower than lorum at base, not produced beyond gena, apical margin straight. Lorum apex widely distant from gena margin, inner margin bordering postclypeus for more than one third of its length. Antenna short, inserted near posteroventral corner of eye, mesal margin of eye entire. 
Thorax. Pronotum wider than long, anterior margin convex, posterior margin straight. Scutellum wider than long. Macropterous, forewing veins not carinate, appendix restricted to anal margin, with three anteapical cells, without reflexed costal veins, with $\mathrm{A} 1-\mathrm{A} 2$ and $\mathrm{r}-\mathrm{m} 1$ crossveins. Hindwing submarginal vein complete.

Legs. Profemur row AM with AM1, one intercalary row with more than five fine setae gradually reduced apically, two dorsoapical setae, AV with numerous short stout setae, dorsal margin rounded with fine hairs. Protibia AD and PD row each with four macrosetae, AV row with numerous macrosetae gradually increasing in size apically. Mesofemur AV row with stout and short setae, two apical setae. Mesotibia AD and $\mathrm{PD}$ row each with four macrosetae, $\mathrm{AV}$ row with numerous macrosetae. Metafemur setal formula $2+2+1$. Metatibia PD and AD row with long and short macrosetae, three smaller intercalary setae between each pair; AV and PV row with numerous macrosetae extending nearly to base, gradually increasing in size apically. Metatarsomere I shorter than tarsomeres II plus III combined.

Abdomen. Sternal male apodemes parallel-sided, apically angulate, apodeme width equal to distance between each apodeme (Fig. 37).

Male genitalia (Figs 30-36). Pygofer long with well-developed macrosetae, ventral margin serrate, curved inside (Fig. 34). Genital valve free and with pointed articulation to pygofer (Fig. 36). Subgenital plate with one row of macrosetae near margin and some scattered fine hairs which are short to as long as macrosetae, apical part finger-like, sinuate (Fig. 33). Style bent, small, finger-like, curved preapically, inner side with projection, well-developed preapical lobe and subapical tooth (Fig. 32). Connective articulated with aedeagus, Y-shaped, branches shorter than half of connective total length (Fig. 35). Aedeagus with shaft bifurcate, each branch as long as $2 / 3$ of the total aedeagus length, curved dorsad in lateral view; aedeagus basally with long bifurcate process, pointed at apex, curved dorsad in lateral view, and mesiad apically in dorsal view (Figs 30-31).

Female genitalia (Figs 38-40). Pygofer with numerous macrosetae. Sternite 7 about twice longer than wide, posterior margin curved, with median U-shaped notch in middle, posterolateral angles acutely rounded (Fig. 38). First valvula slightly convex; second valvula blade-like, abruptly broadened basad of tooth section, regularly serrated with small teeth (Figs 39-40).

Remarks. Phlepsopsius is similar to Pseudophlepsius Zachvatkin, 1924 in general habitus and Opsius Fieber, 1866 in the male genitalia. Phlepsopsius can be distinguished easily from Pseudophlepsius by the aedeagus shafts not robust and without a projection on the outer side, and pygofer without appendages. From Opsius, Phlepsopsius can be distinguished by the anterior margin of head carinate, transition of vertex to frons forming a distinct angle.

Distribution. North Africa and Arabian Peninsula (Figs 51-52).

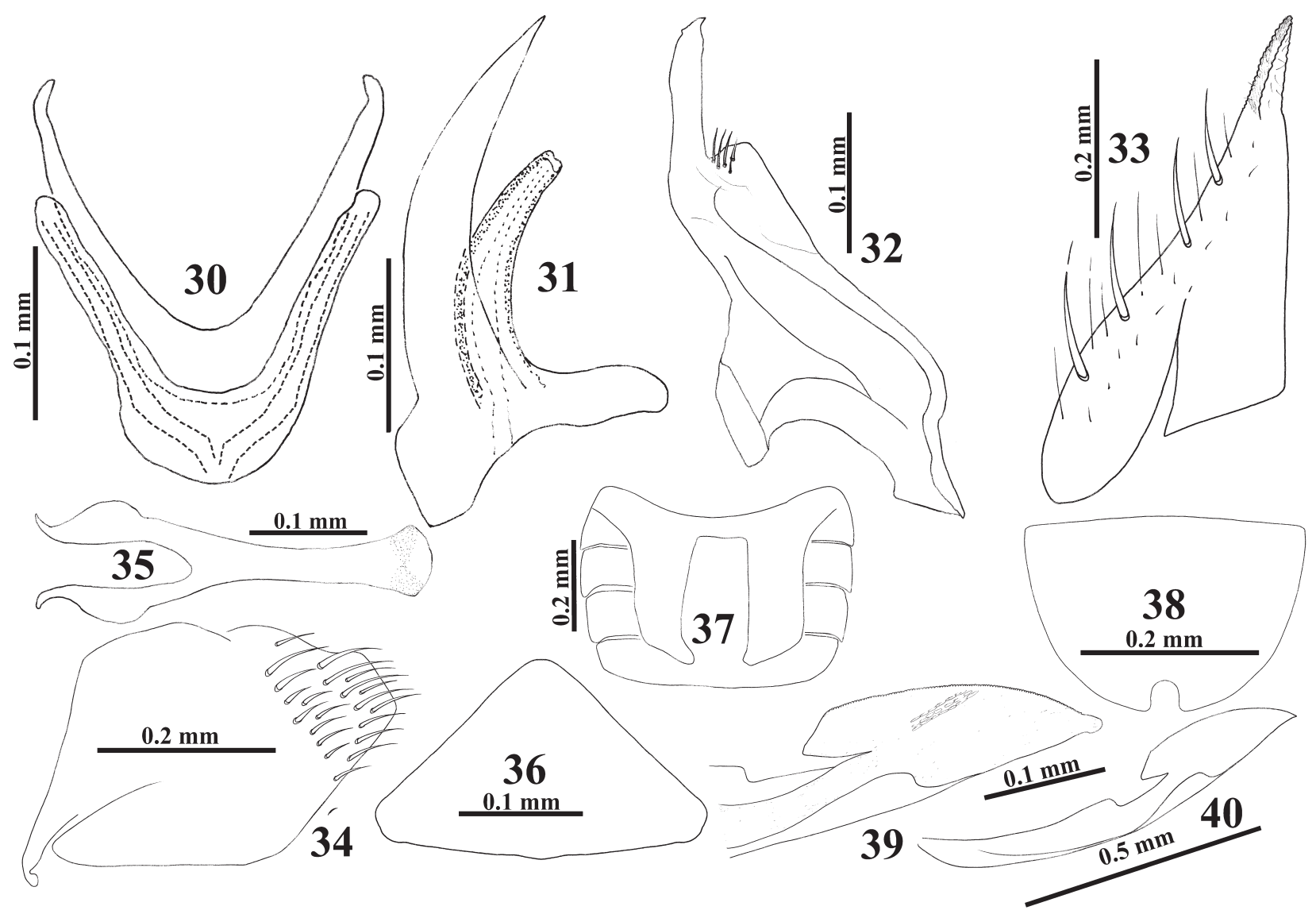

Figs 30-40. Phlepsopsius arabicus Dlabola, 1979. 30 - aedeagus, dorsal view; 31 - aedeagus, lateral view; 32 - style; 33 - subgenital plate; 34 - pygofer; 35 - connective; 36 - valve; 37 - apodemes; 38 - female 7th sternite; 39 - detail of ovipositor apex; 40 - ovipositor, lateral view. 
Phlepsopsius arabicus Dlabola, 1979

(Figs 3-4, 9-10, 30-40)

Phlepsopsius arabicus Dlabola, 1979: 132.

Phlepsopsius africanus Abdul-Nour, 2007: 303, syn. nov.

Type material examined. P. africanus: HoLOTYPE: ô, LIBYA: Mizdah (Tripolitania), 2.ix.2005, P. Weill leg. (MNHN).

Additional material examined. KINGDOM OF SAUDI ARABIA: RIYADH: 11 우 $4 \hat{\delta} \hat{o}$, Ibex Reserve National Park, Wadi Hutet Beni Tamem, $180 \mathrm{~km} \mathrm{~S}$ of Riyadh, 7.v.2012, light trap, $23^{\circ} 27.133^{\prime} \mathrm{N}$, $46^{\circ} 41.281^{\prime} \mathrm{E}, 676 \mathrm{~m}, \mathrm{H}$. Al Dhafer, M. Abdel-Dayem, A. El Torky \& A. Al-Ansi leg.; 1 , Muzahimiyah, Al Khararah, 7.vi.2011, light trap, $24^{\circ} 24.59^{\prime} \mathrm{N}, 46^{\circ} 14.74^{\prime} \mathrm{E}, \mathrm{Y}$. Al Drayhim, H. Al Dhafer, A. El-Gharbawy \& H. Setyaningrum leg.; $1 \hat{\jmath}$, same but 5.v.2015; $1 \hat{\delta}$, same but 26.iv.2011; 7 우 8 ô. Al Aflag, Al Naifiyah, Farshet Sheaal, 10.iv.2015, light trap, $22^{\circ} 24.935^{\prime} \mathrm{N}, 46^{\circ} 35.287^{\prime} \mathrm{E}, 599 \mathrm{~m}, \mathrm{H}$. Al Dhafer, M. Abdel-Dayem, A. El Torky, A. Elgharbawy \& A. Soliman leg. Asir: 1 ㅇ, Wadi Targ, 14.iii.2012, light trap, $19^{\circ} 37.385^{\prime} \mathrm{N}, 42^{\circ} 18.020^{\prime} \mathrm{E}, 1317 \mathrm{~m}$, H. Fadhallah \& H. Setyaningrum leg.; 1 , Abha, Al-Hubail, Wadi Reem, 17.x.2014, light trap, $18^{\circ} 06.981^{\prime} \mathrm{N}, 42^{\circ} 13.939^{\prime} \mathrm{E}, 451 \mathrm{~m}$, Al Harbi \& I. Rasool leg.; 8 $\circ 96{ }^{\circ}$, Al Magardah, Wadi Yabah, 11.x.2013, light trap, 19²14.911'N, $41^{\circ} 47.200^{\prime}$ E, 402 m, S. El-Sonbati, I. Rasool, M. Al Harbi \& S. Khan leg.; 1 'ै, Al Magardah, Wadi Tourabah, 1.v.2012, light trap, $20^{\circ} 14.369^{\prime} \mathrm{N}$, $41^{\circ} 15.234^{\prime} \mathrm{E}, 1757$ m, H. Al Dhafer, M. Abdel-Dayem, A. Al-Ansi \& A. Al-Othman leg.; 1 o, Al Magardah, Wadi Talalea, 12.x.2013, light trap, $19^{\circ} 02.740^{\prime} \mathrm{N}, 41^{\circ} 46.333^{\prime} \mathrm{E}, 259 \mathrm{~m}$, S. El-Sonbati leg. ВАнAн: 1 , Shada Al Ala, 24.iv.2014, light trap, $1^{\circ} 52.598^{\prime} \mathrm{N}, 41^{\circ} 18.672^{\prime} \mathrm{E}, \mathrm{H}$. Al Dhafer \& S. El-Sonbati leg. JAZAN: 1 , Fifa, Al Abasia, 1.v.2014, suction sampling, $17^{\circ} 15.831^{\prime} \mathrm{N}, 43^{\circ} 05.498^{\prime} \mathrm{E}$, S. El-Sonbati leg. Маккан: 1 웅, Taif, Sadai- rah, 24.x.2013, baiting trap, $21^{\circ} 24.962^{\prime} \mathrm{N} 40^{\circ} 33.065^{\prime} \mathrm{E}$.; 1 , Mahazat As Sayd, 23.xi.2011, baiting trap, $22^{\circ} 14.678^{\prime} \mathrm{N} 41^{\circ} 50.428^{\prime} \mathrm{E}$ (all KSMA).

Redescription. The only species in the genus, see the generic redescription.

Distribution (Figs 51-52). Libya (ABDUL-Nour 2007), KSA (Dlabola 1979). In KSA, widely distributed in the central region including several areas, e.g. Al Aflag and Muzahimiyah, Al Khararah, and in the southwestern region, e.g. Shada Al A'la protectorate in $\mathrm{Al}$ Bahah province and Raydah protectorate in Asir province (Fig. 54), which is considered the richest area for biodiversity in Saudi Arabia (Hegazy et al. 1998).

Ecology and biology. The abundance of $P$. arabicus is significantly higher in April and October. Most specimens were collected at light and no host plants can be given.

Remarks. Phlepsopsius africanus Abdul-Nour, 2007 is proposed here to be a new junior subjective synonym of P. arabicus based on the examination of the male holotype of $P$. africanus, which has identical genitalia to numerous specimens collected in KSA.

\section{Hishimonus Ishihara, 1953}

Hishimonus Ishihara, 1953: 38. Type species: Thamnotettix sellatus Uhler, 1896: 294 , by original designation.

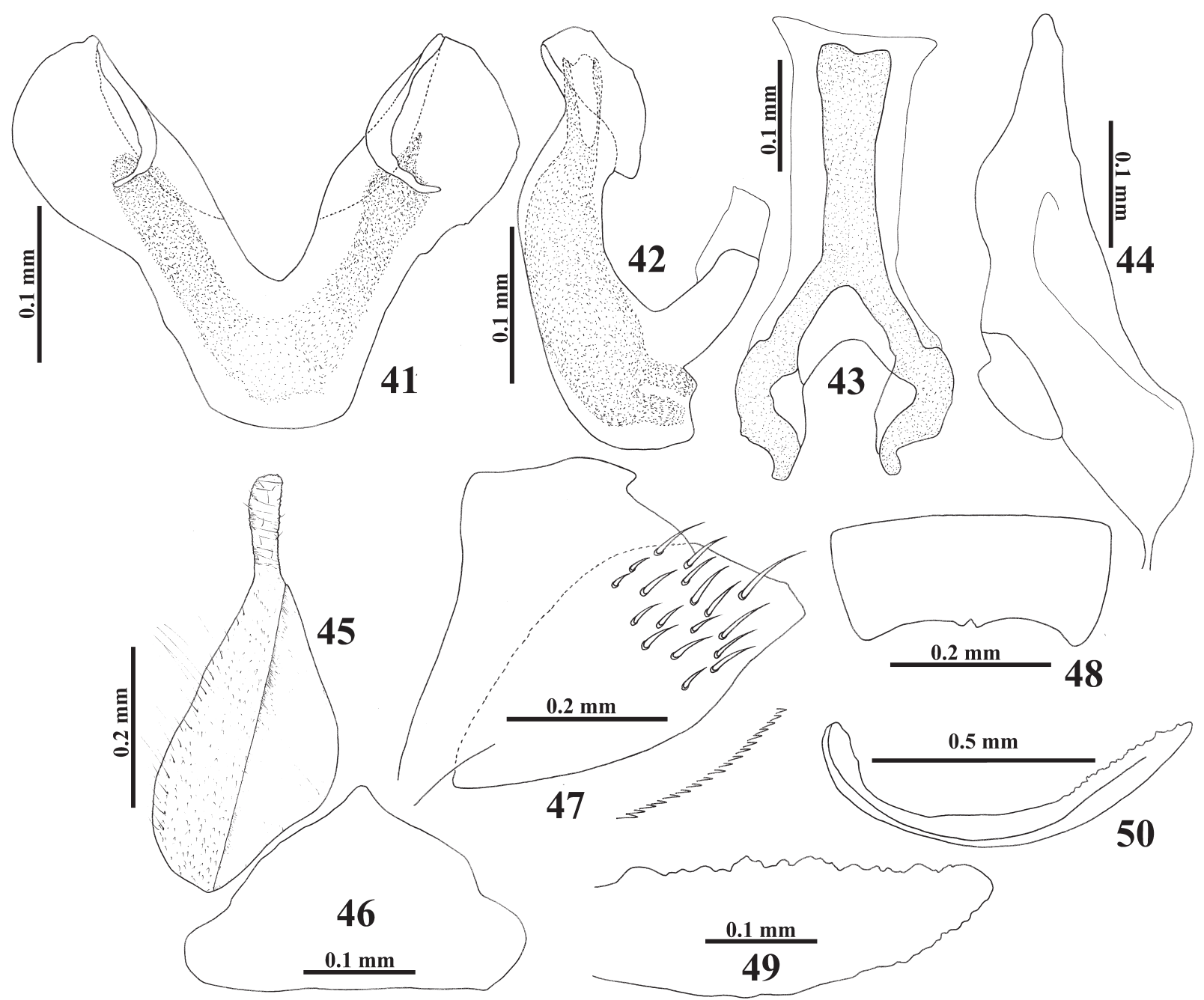

Figs 41-50. Hishimonus phycitis (Distant, 1908). 41 - aedeagus, dorsal view; 42 - aedeagus, lateral view; 43 - connective; 44 - style; 45 - subgenital plate; 46 - valve; 47 - pygofer; 48 - female 7th sternite; 49-50 - ovipositor, lateral view. 

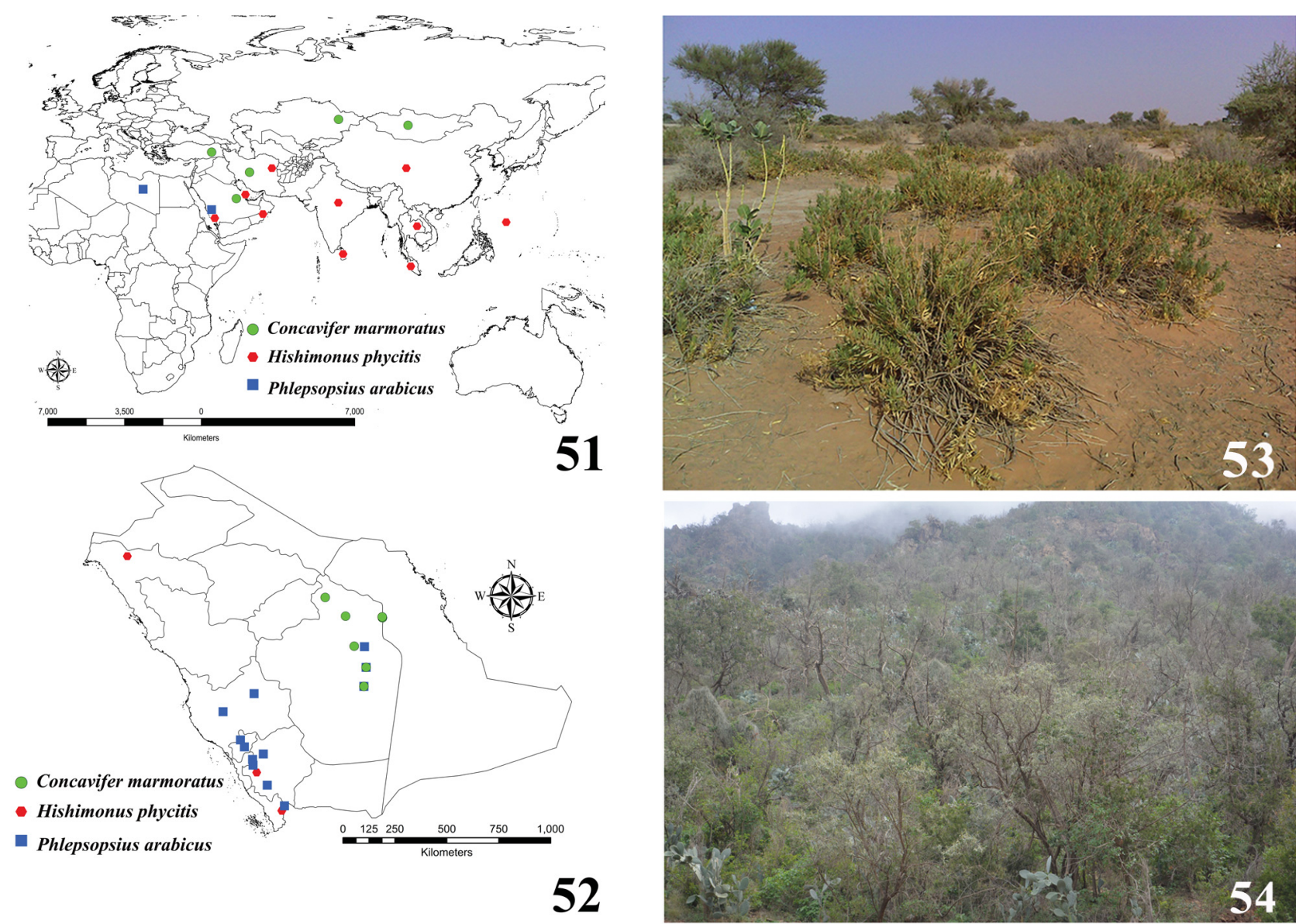

Figs 51-54. 51-52 - distribution of Concavifer spp., Phlepsopsius arabicus Dlabola, 1979 and Hishimonus phycitis (Distant, 1908) (51 - distribution at global scale; 52 - distribution in the Kingdom of Saudi Arabia). 53-54 - habitats of Concavifer and Phlepsopsius spp. 53 - locality of Concavifer marmoratus Dlabola, 1960 and Phlepsopsius arabicus in Rhodet Khorim, Ramah governorate, Saudi Arabia; 54 - locality of Phlepsopsius arabicus and Hishimonus phycitis in Raydah Protectorate, Saudi Arabia.

Diagnosis. Hishimonus is similar to Naevus Knight, 1970, Hishimonoides Ishihara, 1965, and Litura Knight, 1970. Hishimonus can be recognised easily from Naevus and Litura by the atrium of the aedeagus not extended ventrad beyond the shafts; and from Hishimonoides by the absence of a pair of well-developed ventral paraphyses on the aedeagus. Description. Detailed generic descriptions can be found in Knight (1970), Dai et al. (2013) and Viraktamath \& Murthy (2014).

\section{Hishimonus phycitis (Distant, 1908)}

(Figs 5-6, 11-12, 41-50)

Eutettix phycitis Distant, 1908: 363; MetCALF (1968: 483).

Hishimonus phycitis: NIELSON (1968: 303); IsHIHARA (1969: 244).

Cestius (Hishimonus) phycitis: SingH (1971: 571); BINDRA (1973: 18).

Eutettix phyciitis [sic!]: GHosh \& GHosh (1994: 30).

Eutettix lugubris Distant, 1918: 60; Metcalf (1968: 476). Synonymy by KNIGHT (1970: 128).

Hishimonus orientalis Emeljanov, 1969: 1102. Synonymy by KNIGHT (1970: 128).

Material examined. KINGDOM OF SAUDI ARABIA: AsIR: 19 , Saloo Almanzar W of Baqrah, 4.xi.2013, light trap, $18^{\circ} 47.511^{\prime} \mathrm{N}, 42^{\circ} 01.090^{\prime} \mathrm{E}$, 422 m, H. Al Dhafer, H. Fadl, M. Abdel-Dayem \& A. El Torky leg. JAzAN: $2 \hat{\partial}$, Fiyfa, Al Absisa Mountains, 20.iii.2014, suction sampling, $17^{\circ} 15.831^{\prime} \mathrm{N} 43^{\circ} 06.498^{\prime} \mathrm{E}, 1770 \mathrm{~m}$, S. El-Sonbati leg.; 1 o, same but Al Dayer, $17^{\circ} 20.223^{\prime} \mathrm{N} 43^{\circ} 07.539^{\prime} \mathrm{E}$ (all KSMA). TAвUK: 13 우 11 ठे, Tabuk City, Maksarin Sahara Hotel grounds, $28^{\circ} 24.566^{\prime} \mathrm{N} 36^{\circ} 35.716^{\prime} \mathrm{E}$, 8.iv.2013, ex Dodonaea viscosa, M. R. Wilson leg. (NMWC).
Diagnosis. Hishimonus phycitis has been adequately redescribed by KNIGHT (1970), DAI et al. (2013) and Viraktamath \& Murthy (2014). Here we list only the diagnostic characters: Head as wide as pronotum, both greenish yellow, without spots; wings with large brown spot and scattered small patches; subgenital plate gradually tapered at base, with finger-like lobe; stylus with apical lobe straight, preapical lobe not well-differentiated; aedeagus shafts abruptly divergent, with apically enlarged posteromedial lobe.

Economic importance. The genus Hishimonus is known as a vector of Witches' broom disease of lime (WBDL) considered one of the most lethal plant pathogens and widely distributed in the Arabian Peninsula (SHABAnI et al. 2011, 2013; Al-SAleh \& Amer 2014).

Distribution. Iran, United Arab Emirates, Oman, India, Sri Lanka, China, Malaysia, Thailand, Australia (MetCalf 1967, KNight 1970, ZReiK et al. 1995, SALEHI et al. 2007, DAi et al. 2013) and KSA (new records). In KSA, the species has been recorded in low abundance from the southwestern and Tabuk regions and is considered uncommon for Saudi Arabia.

\section{Acknowledgements}

The authors are grateful to John Deeming (NMWC) for the valuable suggestions, to James Turner (NMWC) for 
helping in photographing specimens, to Boris Kondratieff, Colorado State University, for reading the manuscript, and to Igor Malenovský for his helpful editorial comments. The authors would like to extend their sincere appreciation to the Deanship of Scientific Research at King Saud University for funding their research group (no. RGP-1437-009).

\section{References}

ABDUL-NOUR H. 2007: Cicadellidae de Libye: description d'espèces nouvelles ou peu connues (Hemiptera, Cicadomorpha). Nouvelle Revue d'Entomologie (Nouvelle Série) 23: 301-308.

ALFARHAN A. H. 2001: A floristic account on Raudhat Khuraim Central Province Saudi Arabia. Saudi Journal of Biological Sciences 8: 80-103.

ALHUDAIB K., AROCHA Y., WILSON M. \& JONES P. 2009: Molecular identification, potential vectors and alternative hosts of the phytoplasma associated with a lime decline disease in Saudi Arabia. Crop Protection 28: 13-18.

AL-SALEH M. A. \& AMER M. A. 2014: Molecular characterization of the 16 sr ii group of phytoplasma associated with faba bean (Vicia faba L.) in Saudi Arabia. Journal of Animal and Plant Sciences 24: 221-228.

BINDRA O. S. 1973: Studies on Indian Cicadellidae with special reference to Circulifer and related genera and their importance as vectors of plant pathogens. Final Research Report, PL 480 Project (47-Ent-22). Punjab Agricultural University, Ludhiana, $56 \mathrm{pp}$.

DAI W., FLETCHER M. J. \& ZHANG Y. 2013: First records of the genus Hishimonus Ishihara from Thailand (Hemiptera: Cicadellidae: Deltocephalinae: Opsiini) including description of three new species. Zootaxa 3670: 301-316.

DIETRICH C. H. 2005: Keys to the families of Cicadomorpha and subfamilies and tribes of Cicadellidae (Hemiptera: Auchenorrhyncha). Florida Entomologist 88: 502-517.

DLABOLA J. 1960: Iranische Zikaden (Homoptera, Auchenorrhyncha). (Ergebnisse der Entomologischen Reisen Willi Richter, Stuttgart, in Iran 1954 und 1956, Nr. 31). Stuttgarter Beiträge zur Naturkunde 41: 1-24.

DLABOLA J. 1979: Insects of Saudi Arabia. Homoptera. Fauna of Saudi Arabia 1: 115-139.

DLABOLA J. 1980: Insects of Saudi Arabia. Homoptera: Auchenorrhyncha (Part 2). Fauna of Saudi Arabia 2: 74-94.

DLABOLA J. 1987: Neue Zikadenarten von Saudi Arabien (Homoptera: Auchenorrhyncha). 3. Teil. Annotationes Zoologicae et Botanicae 177: $1-11$.

DMITRIEV D. A. 2002: Larvae of the leafhopper subfamily Deltocephalinae (Homoptera, Cicadellidae) from European part of Russia and adjacent territories. I. A key to tribes and review of the tribes Drabescini, Scaphytopiini, Hecalini, Limotettigini, and Opsiini. Entomologicheskoe Obozrenie 81: 627-661 (in Russian, English translation published in Entomological Review 82: 975-1002).

EL-SONBATI S. A., WILSON M. R. \& AL DHAFER H. M. 2015: A new species of the leafhopper genus Naevus Knight, 1970 (Hemiptera: Cicadellidae: Deltocephalinae: Opsiini), from Saudi Arabia. Zootaxa 4059: 393-400.

EL-SONBATI S. A., WILSON M. R. \& AL DHAFER H. M. 2016 : Paraorosius, a new genus of leafhopper (Hemiptera: Cicadellidae: Deltocephalinae: Opsiini), with description of a new species from the Middle East. Zootaxa 4150: 581-590.

EL-SONBATI S. A., WILSON M. R. \& AL DHAFER H. M. 2017: A new leafhopper genus with two new species related to Masiripius Dlabola 1981 (Hemiptera, Deltocephalinae, Cicadellidae, Opsiini). European Journal of Taxonomy 308: 1-24.

EMELJANOV A. F. 1962: New tribes of leafhoppers of the subfamily Euscelinae (Auchenorrhyncha, Cicadellidae). Entomologicheskoe Obozrenie 41: 388-397 (in Russian with English summary, English translation published in Entomological Review 41: 236-240).

EMELJANOVA. F. 1972: New leafhoppers from the Mongolian People's Republic (Homoptera, Auchenorrhyncha). Insects of Mongolia 1: 199-260 (in Russian).

EMELJANOV A. F. 1999: A key to genera of the subfamily Deltocephalinae s. 1. (Homoptera, Cicadellidae) of Kazakhstan, Middle Asia, and Mongolia, with description of new genera and subgenera. Entomolo gicheskoe Obozrenie 78: 589-609 (in Russian with English summary, English translation published in Entomological Review 79: 547-562).

FLETCHER M. J. \& DAI W. 2018: A new genus Austrimonus for Eutettix melaleucae Kirkaldy (Hemiptera: Cicadellidae: Deltocephalinae: Opsiini) and nine new species. Zootaxa 4387: 310-330.
GHOSH L. K. \& GHOSH M. 1994: Insecta: Hemiptera. Pp. 29-68. In: the DIRECTOR, ZOOLOGICAL SURVEY OF INDIA (ed.): Fauna of West Bengal, Part 5. Zoological Survey of India, Calcutta, 665 pp.

HAUPT H. 1927: Homoptera Palaestinae I. Bulletin of the Institute of Agriculture and Natural History, Tel-Aviv 8: 1-43.

HEGAZY A. K., EL-DEMERDASH M. A. \& HOSNI H. A. 1998: Vegetation, species diversity and floristic relations along an altitudinal gradient in south-west Saudi Arabia. Journal of Arid Environments 38: 3-13.

ISHIHARA T. 1969: Families and genera of leafhopper vectors. Pp. 235-254. In: MARAMOROSCH K. (ed.): Viruses, vectors, and vegetation. Interscience Publishers, New York, 666 pp.

KARTAL V. 1982: Neue Homopteren aus der Türkei. Priamus 1: 24-30. KNIGHT W. J. 1970: A revision of the genus Hishimonus Ishihara (Hom., Cicadellidae). Suomen Hyonteistieteellinen Aikakaukirja 36: 125-139.

LINNAVUORI R. 1962: Hemiptera of Israel. 3. Annales Zoologici Societatis Zoologicae-Botanicae Fennicae ‘Vanamo' (Series 3) 24: 1-108.

MARDI M., KHAYAM NEKOUEI S., FARSAD L. K., EHYA F., SHABANI M., SHAFIEE M. \& HOSSEINI SALEKDEH G. 2011: Witches' broom disease of Mexican lime trees: disaster to be addressed before it will be too late. Bulletin of Insectology 64(Supplement): 205-206.

METCALF Z. P. 1968: General Catalogue of the Homoptera. Fascicle VI: Cicadelloidea. Part 17: Cicadellidae. United States Department of Agriculture, Agriculture Research Service, Washington D. C., 1513 pp.

NIELSON M. W. 1968: The leafhopper vectors of phytopathogenic viruses (Homoptera, Cicadellidae): taxonomy, biology, and virus transmission. Technical Bulletin No. 1382. Agricultural Research Service, United States Department of Agriculture, Washington D. C., 386 pp.

NIELSON M. W. \& KNIGHT W. J. 2000: Distribution patterns and possible origin of leafhoppers (Homoptera, Cicadellidae). Revista Brasileira de Zoologia 17: 81-156.

OMAN P. W., KNIGHT W. J. \& NIELSON M. W. 1990: Leafhoppers (Cicadellidae): A bibliography, generic check-list and index to the world literature 1956-1985. CAB International, Wallingford, $368 \mathrm{pp}$.

PARRELLA G., PALTRINIERI S., BOTTI S. \& BERTACCINI A. 2008: Molecular identification of phytoplasmas from virescent Ranunculus plants and from leafhoppers in southern Italian crops. Journal of Plant Pathology 90: 537-543.

SALEHI M., IZADPANAH K., SIAMPOUR M., BAGHERI A. \& FAGHIHI S. M. 2007: Transmission of 'Candidatus Phytoplasma aurantifolia' to Bakraee (Citrus reticulata hybrid) by feral Hishimonus phycitis leafhoppers in Iran. Plant Disease 91: 466-466.

SHABANI M., BERTHEAU C., ZEINALABEDINI M., SARAFRAZI A., MARDI M., NARAGHI S. M. \& SHOJAEE M. 2013: Population genetic structure and ecological niche modelling of the leafhopper Hishimonus phycitis. Journal of Pest Science 86: 173-183.

SHABANI M., MARDI M., SARAFRAZI A., NARAGHI S. M., RAHIMIAN H., SHOJAEE M. \& ZEINOLABEDINI M. 2011: Isolation and characterization of novel microsatellite markers from the leafhopper Hishimonus phycitis Distant (Hemiptera: Cicadellidae). Conservation Genetics Resources 3: 493-495.

SINGH S. 1971: Hishimonus Ishihara, 1953 and Hishimonoides Ishihara 1965 as synonyms of Cestius Distant, 1908 (Cicadellidae: Hemiptera). Journal of Natural History 5: 569-571.

VIRAKTAMATH C. A. \& MURTHY H. V. 2014: Review of the genera Hishimonus Ishihara and Litura Knight (Hemiptera: Cicadellidae) from the Indian subcontinent with description of new species. Zootaxa 3785: 101-138.

ZAHNISER J. N. 2018: An online interactive key and searchable database of Deltocephalinae (Hemiptera: Cicadellidae). Available online: http://zahniser.speciesfile.org (accessed on 10 March 2018).

ZAHNISER J. N. \& DIETRICH C. H. 2008: Phylogeny of the leafhopper subfamily Deltocephalinae (Insecta: Auchenorrhyncha: Cicadellidae) and related subfamilies based on morphology. Systematics and Biodiversity 6: 1-24.

ZAHNISER J. N. \& DIETRICH C. H. 2013: A review of the tribes of Deltocephalinae (Hemiptera: Auchenorrhyncha: Cicadellidae). European Journal of Taxonomy 45: 1-211.

ZHURAVLEV Y. D. 1991: New species of leafhoppers g. Concavifer Dlab. (Homoptera, Cicadellidae) from desert of south-west Prybalkhashya. Izvestiya Akademii Nauk Kazakhskoi SSR Seriya Biologicheskaya 3: 85-87 (in Russian).

ZREIK L., CARLE P., BOV J. M. \& GARNIER M. 1995: Characterization of the mycoplasma-like organism associated with witches'-broom disease of lime and proposition of a Candidatus taxon for the organism, "Candidatus phytoplasma aurantifolia". International Journal of Systematic Bacteriology 45: 449-453. 